\title{
Long term evaluation of high tibial valgus osteotomy
}

\author{
J. R. Valenti, R. Calvo, R. Lopez, and J. Cañadell
}

Department of Orthopaedic Surgery and Traumatology, University Clinic of Navarra, Pamplona, Spain

Offprint requests to: J. R. Valenti,

Departmento de Cirurgía Ortopedica, Clínica Universitaria de Navarra, Avda. Pio XII s/n 31008, Pamplona, Navarra, Spain

\section{SUMMARY}

We present a long term evaluation of 100 high valgus tibial osteotomies with a mean follow up of 11 years. Knees with slight or moderate osteoarthritis had the best results. Slight overcorrection was beneficial, but gross overcorrection was not. There were few complications and the overall long term results were good.

\section{RÉSUMÉ}

Nous présentons une évaluation à long terme de cent ostéotomies de valgisation de l'extrémité supérieure du tibia, avec un recul moyen de 11 ans. Ce sont les genoux atteints d'arthrose minime ou modérée qui ont eu les meilleurs résultats. Les hypercorrections légères ont été bénéfiques mais non les hypercorrections excessives. Il n'y a eu que peu de complications et dans l'ensemble les résultats à long terme ont été bons.

\section{INTRODUCTION}

A varus deviation of the tibia alters the mechanical axis of the limb and progressive medial compartment osteoarthritis may develop. In 1958, Jackson reported the value of tibial osteotomy in the treatment of pain in osteoarthritis of the knee [19, 20]. Since then various types of osteotomy have been described, all of which aim to correct deformity and reduce the excessive load-bearing through the medial compartment. The aim of this study is to assess the long term results of the Coventry technique [6-11].

\section{MATERIALS AND METHODS}

Two hundred and forty-five tibial osteotomies carried out in our hospital from 1970 to 1988 were studied. Of there, 100 osteotomies in 79 patients, with a minimum follow up of 8 years, were evaluated. 
The patients were assessed clinically and radiologically before and after operation, and at the final review for this study. There were $45(57 \%)$ women and $34(46 \%)$ men with a mean age of 56 years (range 17-74). The right knee was affected in $51 \%$, the left in $49 \%$, and both in $21 \%$.

The main reason for operation was pain in 66 knees, pain and deformity in 24, pain, deformity and laxity in 4, and deformity alone in 6 . Pain was associated with daily activity in 43 knees, with special exertion in 32, at rest in 15, and there was no pain in 6. Details were not available for 4 knees.

Osteoarthritis was graded as slight in 33 knees (group 1), moderate in 46 (group 2), and severe in 21 (group 3).

The pre-operative varus deformity was on average $7.1^{\circ}$ (minimum $0^{\circ}$, maximum $20^{\circ}$ ). The average flexion contracture before operation was $3.2^{\circ}$ (minimum $0^{\circ}$, maximum $25^{\circ}$ ), and the average range of flexion was $116^{\circ}$ (minimum $80^{\circ}$, maximum $130^{\circ}$ ).

Nine patients had undergone a previous medial meniscectomy, and one a lateral meniscectomy. Five suffered from rheumatoid arthritis, 3 had previous fractures and one an osteotomy.

The valgus osteotomy was carried out above the tibial tuberosity. In 32 cases we displaced the tibial tuberosity forwards as described by Maquet $[22,27]$. The ligaments of the upper tibio-fibular syndesmosis were sectioned $[2,5]$ rather than removing the head of the fibula. The mean follow up was 11 years (minimum 96 months, maximum 196 months); $51 \%$ were over 11 years from operation.

\section{RESULTS}

The average angle of osteotomy was $18.4^{\circ}$ (minimum $10^{\circ}$, maximum $25^{\circ}$ ); most $(90 \%)$ were Between $10^{\circ}$ and $20^{\circ}$. The mean valgus angle after operation was $9.3^{\circ}$ (minimum $0^{\circ}$, maximum $15^{\circ}$ ); the angle at follow up was $6.8^{\circ}$ (minimum $0^{\circ}$, maximum $20^{\circ}$ ). At follow up, the average flexion contracture was $2.4^{\circ}$ (minimum $0^{\circ}$, maximum $20^{\circ}$ ) and the average range of flexion was $100^{\circ}$ (minimum $65^{\circ}$, maximum $130^{\circ}$ ).

The best results as regards relief of pain were in knees with mild or moderate osteoarthritis. The knees were divided into 3 groups in relation to the correction achieved: undercorrection (valgus $<3^{\circ}$ or varus); standard correction (from valgus $>3^{\circ}$ to $<8^{\circ}$ ), and overcorrection (valgus $>8^{\circ}$ ).

All the knees which were undercorrected were painful at follow up, $60 \%$ during normal activity and $40 \%$ during exertion. In the knees with standard correction, $43.7 \%$ had no symptoms, $18.7 \%$ had pain on exertion and $18.7 \%$ had pain at rest.

In the overcorrected group, $39.2 \%$ had no symptoms, $20.3 \%$ had pain on exertion, $35.1 \%$ had pain on daily activity and $5.4 \%$ had pain at rest. Of those with overcorrection between $8^{\circ}$ and $10^{\circ}$ (Fig. 1), $66.7 \%$ had no symptoms, $14.7 \%$ had pain on exertion and $19 \%$ had pain during daily activity. Of those with overcorrection of more than $10^{\circ}$, 
$55.4 \%$ had no symptoms, $28.6 \%$ had pain on exertion, $42.5 \%$ had pain on daily activity, and $7.5 \%$ had pain at rest (Fig. 2).

There was a $4 \%$ incidence of thrombophlebitis in the series, but there were no wound infections, no lesions of the lateral popliteal nerve and no loosening of the fixation. Further operation was necessary in $8 \%$, with knee replacement in $5 \%$, excision of the patella in $1 \%$ and other procedures in $2 \%$.

\section{DISCUSSION}

Although many papers have been published on high tibial osteotomy [1, 3, 4, 12, 13, $26]$, there have been few reports of the long term results $[11,14,15,28]$.

Our series is similar to that of others with regard to the numbers studied, and the age and sex of the patients $[17,18,24]$. In most cases pain was the predominant symptom and was present in $66 \%$ of our cases; $25 \%$ had both pain and deformity. There was no difference in the measurement of movement before operation, after operation or at follow up, and this was the case in other reports $[9,17,18]$. We agree with Insall [17, 18] that instability is the main criterion for deciding on treatment, but we have not analysed this factor individually. We have preferred to consider the severity of the osteoarthritis, since the most severely affected knees are usually unstable and the worst long term results are found in this group.

Most patients had short term relief of pain [21, 22, 23, 29, 30], but in many the pain recurred as has been noted by others $[17,18,24]$, especially when the changes were severe and there was excessive under- or over correction. The long term results were good in patients with slight or moderate osteoarthritis and with satisfactory correction, or slight over correction.

Unlike other studies, we had a low complication rate and only 5\% required a knee replacement later, which contrasts with Insall's report [18].

We consider that correction should be between $3^{\circ}$ and $10^{\circ}$, the ideal being between $8^{\circ}$ and $10^{\circ}$, the best results being in this group. In knees with normal alignment we do not carry out an overcorrected osteotomy because these patients do not usually have symptoms referable to the medial tibiofemoral compartment. The Coventry valgus osteotomy is the best technique in patients with unicompartmental osteoarthritis who are under 65 years of age [18] with slight or moderate radiological changes. Pain is relieved and knee replacement is avoided in most cases.

\section{REFERENCES}

1. Bastiani G, Detrinchi E, Turi G (1977) La osteotomia tibial en la artrosis de la rodilla. Rev Ortop Traum 21 IB: 539-542

2. Bauer G, Insall J, Koshino T (1969) Tibial osteotomy in gonarthrosis. J Bone Joint Surg [Am] 51: 1545-1563

3. Blaimont P, Burnotte J, Halleux P (1975) La préarthrose du genou. Pathogénie, biomécanique et traitement prophylactique. Acta Orthop Belg 41: 177-200 
4. Blanchard J, Lord G, Marotte J, Guillamon J, Besse J (1979) Ostéotomies tibiales de valgisation. Chir Orthop 65: 209-219

5. Cañadell J, Imizcoz J, Valenti J, Villas C, Oriaifo (1980) Osteotomies in the treatment of gonarthrosis. Arch Orthop Traum Surg 97:91-94

6. Coventry M (1965) Osteotomy of the upper portion of the tibia for degenerative arthritis of the knee. J Bone Joint Surg [Am] 47: 984-990

7. Coventry M (1969) Stepped stable for upper tibial osteotomy. J Bone Joint Surg [Am] 51: 1011

8. Coventry M (1973) Osteotomy about the knee for de-generative and rheumatoid arthritis. J Bone Joint Surg [Am] 55: 23-48

9. Coventry M (1985) Upper tibial osteotomy for osteoarthritis. J Bone and Joint Surg [Am] 67: 1136-1140

10. Coventry M (1987) Proximal tibial varus osteotomy for osteoarthritis of the lateral compartiment of the knee. J Bone Joint Surg [Am] 69: 32-38

11. Coventry M, Bowman P (1982) Long term results of upper tibial osteotomy for degenerative arthritis of the knee. Acta Orthop Belg 48: 139-156

12. Debeyre J, Artigou J (1973) Des indications et les résultats de l'ostéotomie tibiale. Influence de la laxité. Rev Chir Orthop 59: 641-656

13. Fernandez Sabate A, Marin M, Vilarubias J (1980) Tratamiento de la gonartrosis con osteotomia tibial de penetración y fijación con grapa. Rev Ortop Traum 24 IB: $13-26$

14. Goutallier D, Hernigou P, Medevelle D, Debeyre J (1986) Devenir à plus de 10 ans de 93 ostéotomies tibiales effectuées pour gonarthrose interne sur genu varum. Rev Chir Orthop 72: 101-113

15. Hernigou P, Medevielle D, Debeyre J, Goutallier D (1987) Proximal tibial osteotomy for osteoarthritis with varus deformity. A ten to thirteen year follow up study. J Bone Joint Surg [Am] 69: 332-354

16. Ibarra J, Jolin $\mathrm{T}$ (1979) La osteotomia de la tibia en el tratamiento de la gonartrosis. Rev Ortop Traum 14 IB: 183-200

17. Insall J, Shoji H, Mayer V (1974) High tibial osteotomy. A five year evaluation. J Bone Joint Surg [Am] 56: 1397-1405

18. Insall J, Douglas J, Msika C (1984) High tibial osteotomy for varus gonarthrosis. A long term follow up study. J Bone Joint Surg [Am] 66: 1040-1048

19. Jackson J, Waugh W, Green J (1969) High tibial osteotomy for osteoarthritis of the knee. J Bone Joint Surg [Br] 51:88-94

20. Jackson J, Waugh W (1974) The technics and complications of upper tibial osteotomy. J Bone Joint Surg [Br] 56: 236 - 245

21. Jimenez A, Barrientos J, Alvarez M (1982) Tratamiento de las desviaciones axiales en el plano frontal de miembros inferiores, mediante la osteotomia alta de tibia. Rev Ortop Traum 26 IB: 496-506

22. Maquet $P$ (1982) Traitement chirurgical de l'arthrose fémoro-tibiale. Acta Orthop Belg 48: 172-189

23. Marin M, Jimeno F, Cabot J (1985) Osteotomías de rodilla. Coventry o curviplana? Rev Ortop Traum 29 IB: 187-192

24. Myrnerts R (1980) High tibial osteotomy with overcorrection of varus malalignment in medial gonarthrosis. Acta Orthop Scand 51: 557-560

25. Quiles M, Sanz T, Narvaez J (1985) Factores anatómicos en la osteotomia tibial valguizante. Rev Ortop Traum 29 IB: 647-652

26. Quiles M, Sanz T, Narvaez J (1986) Las complicaciones paralíticas de la osteotomia tibial valguizante. Rev Ortop Traum 30 IB: 195-199 
27. Sasaki T, Yagi T, Monji J, Yasuda K, Tsuge H (186) High tibial osteotomy combined with anterior displacement of the tibial tubercle for osteoarthritis of the knee. Int Orthop 10: 31-40

28. Vainionpaa S, Laike E, Kirves P, Tiusanen P (1981) Tibial osteotomy for osteoarthritis of the knee. A five to ten year follow up study. J Bone Joint Surg [Am] 63: 938-945

29. Weill D, Schneider M, Simon G (1981) Les ostéotomies du genou dans le traitement de la gonarthrose. SOFCOT 55ème Congrès, Paris, 1980. Rev Chir Orthop (Supp II) 67: 119-122

30. Williams A (1986) Tibial realigment by oblique wedge osteotomy. Int Orthop 10: $171-176$ 

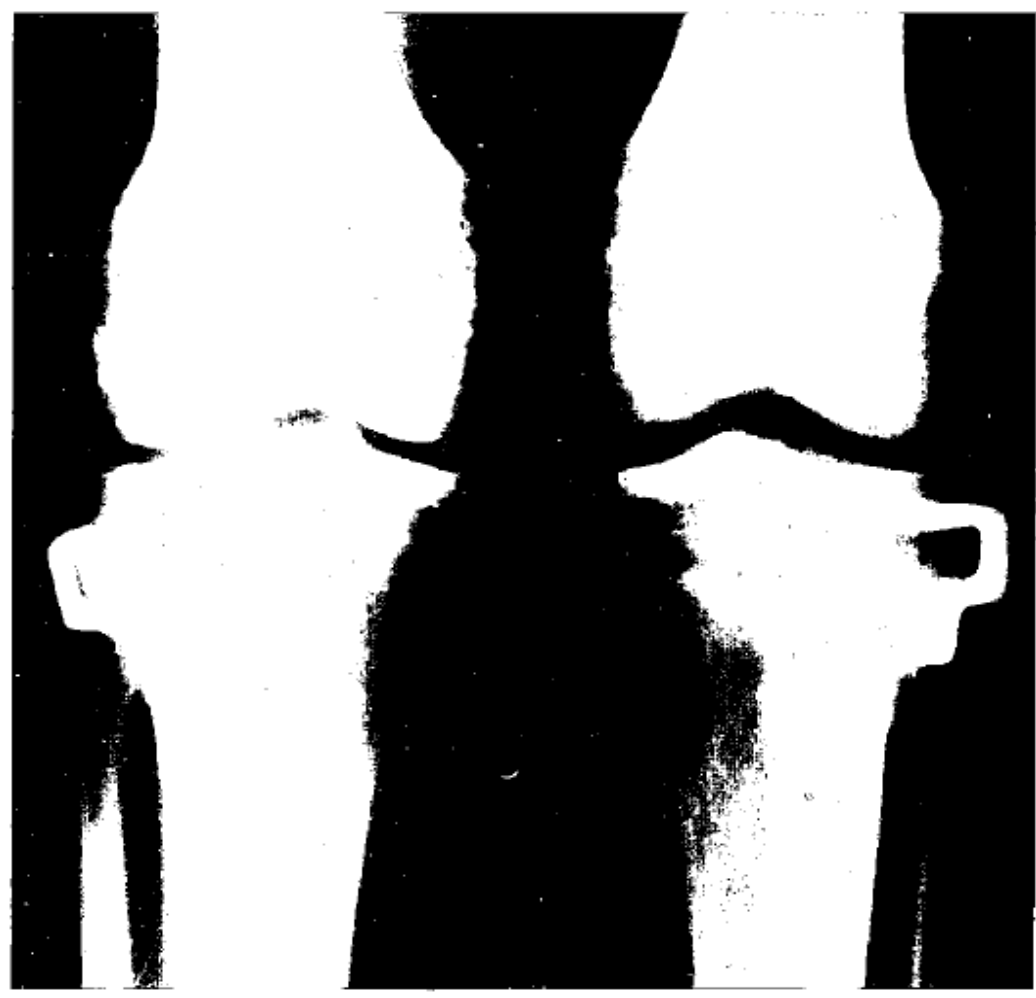

Figure 1. Radiograph showing overcorrection between $8^{\circ}$ and $10^{\circ}, 10$ years after operation
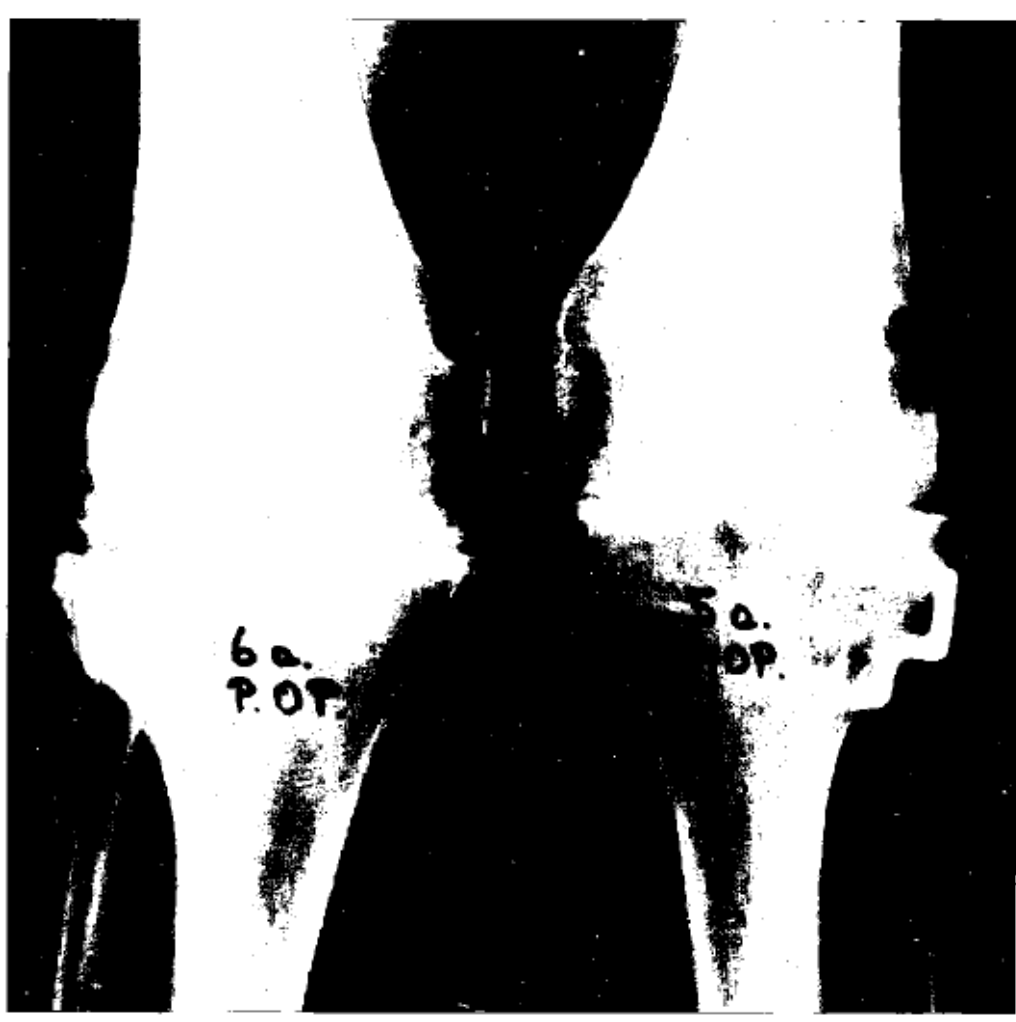

Figure 2. Radiograph showing overcorrection of more than $10^{\circ}, 6$ years after operation; both knees were very painful 